\title{
Comparative study of nutritional evaluation between three types of edible marine fishes of landing site of tuticorin coast and marine market fishes of Madurai District
}

\begin{abstract}
Marine fishes are known to be a good quality source of protein and rich in essential amino acids. Moreover, it contains high amount of monounsaturated and polyunsaturated fatty acids that might favourably improve lipid profiles and reduce risk of coronary heart disease (CHD). The present study was carried out to determine the nutritional evaluation of raw marine fishes of Landing site and market. The result shows that Lutjanus sebae from landing site tend to have the highest moisture content $76.5 \%$, when compared with market fish of $71.3 \%$. The landing site of C. malabaricus had the highest protein and ash content of $19.5 \%$ and $4.56 \%$ whereas the market fish reduced to $14.3 \%$ and $3.12 \%$. The $L$. sebae collected from the landing site had the highest lipid and Carbohydrate content of $3.2 \%$ and $6.6 \%$ whereas the market fish had $1.8 \%$ and $4.5 \%$. Thus the present study revealed that the freshly captured fish have very good nutritional value than the market fishes.
\end{abstract}

Volume 6 Issue 2 - 2017

\author{
M Karthigarani,' G Chelladurai, ${ }^{2} \mathrm{~N}$ \\ Buvaneshwaris' \\ 'Department of Zoology, Yadava College, India \\ ${ }^{2}$ Department of Zoology, G Venkataswamy Naidu College, India
}

Correspondence: M Karthigarani, Department of Zoology,

Yadava College, India Email gcd.zoology@gmail.com

Received: July 28, 2017 | Published: August 30, 2017

Keywords: Edible Marine fishes, Biochemical composition, Landing site, Market, Tuticorin, Madurai

\section{Introduction}

Fish can form a very nutritious part of man's diet rich in most of the vitamins, good selection of minerals and the proteins which contain all the essential amino acids in the right proportions. Although the amount of protein in fish varies a little from species to species and, on occasions, within a species, the protein content of meat and fish is roughly comparable. Fish are a great source of protein, vitamins, and minerals and omega-3 fatty acids, a key nutrient for brain development. ${ }^{1,2} \mathrm{~A}$ well-balanced diet that includes a variety of fish and shellfish can contribute to heart health and children's proper growth and development. ${ }^{3}$ The chemical composition of fish varies greatly from one species and one individual to another depending on age, sex, environment and season. Fish and shellfish are highly perishable, and prone to vast variations in quality due to differences in species, environmental habitats, feeding habits and action of autolysis enzymes as well as hydrolytic enzymes of microorganisms on the fish muscle. ${ }^{4}$ During the past 20 years, however, there has been renewed interest in other dietary components that might favourably improve lipid profiles and reduce risk of coronary heart disease (CHD). Fish and fish oil, rich sources of omega-3 fatty acids, have sparked intense interest in both epidemiological studies, which suggest a favourable effect on CHD, and metabolic ward studies, which show a striking improvement in lipid profiles in hyperlipidemic patients. ${ }^{5}$ Fish meal has been the most important feedstuff used as a source of protein in aquaculture feeds because of its essential amino acid composition and palatability. ${ }^{6}$ Demand for protein ingredients in aquaculture is expected to exceed supply in the next decade. The growth of the aquaculture industry will also raise the price of feedstuffs. ${ }^{7}$ Fish is known to be a source of protein rich in essential amino acids (lysine, methionine, cystine, threonine and tryptophan). ${ }^{8}$ Fish quality is a complex concept involving a whole range of factors, which for the consumer include for example: safety, nutritional quality, availability, convenience, integrity, freshness, eating quality and the obvious physical attributes of the species, size and product type. Information about handling, processing and storage techniques, including time and temperature histories that can affect the freshness and quality of the products is very important for the partners in the chain. ${ }^{9}$

The essential amino acids are lysine, methionine, threonine, tryptophan, isoleucine, leucine, phenylalanine and valine. Failure to obtain enough of even one of the essential amino acids results in the degradation of the muscle proteins in the body. Recent evidence shows that some amino acids and their metabolites are important regulators of key metabolic pathways that are necessary for maintenance, growth, feed intake, nutrient utilization, immunity, behaviour, larval metamorphosis, reproduction, as well as resistance to environmental stressors and pathogenic organisms in various fishes. In recent years, fish lipids have also assumed great nutritional significance owing to their protective role against the development of cardiovascular disease and rheumatoid arthritis. ${ }^{10}$ Hence, consumption of fish, both freshwater and marine, is therefore being encouraged. Hence the present study shows the comparative analysis of biochemical composition of some marine fishes of landing site of Tuticorin and market of Madurai district.

\section{Materials and methods}

\section{Sample collection}

The samples of Elops saurus (Linnaeus, 1766), Lutjanus sebae (G. Cuvier, 1816) and Carangoides malabaricus (Bloch \& Schneider, 1801) were collected from the fishing area of Tuticorin coast and from the Madurai market in the morning and transferred immediately to the laboratory in polythene bags during January 2015 to March 2015.

\section{Preparation of Experimental Tissues for Biochemical analysis}

The tissues were cut with razor, washed with distilled water and blotted with blotting paper. A weighed portion (about $5 \mathrm{~g}$ ) of tissues were homogenized in $3 \mathrm{ml}$ ice - cold saline $(0.89 \% \mathrm{NaCl})$ solution 
for saline extract (for Carbohydrate and protein estimation) and 3 $\mathrm{ml}$ ethanol for ethanol extract (for lipid estimation) in a mortar. The homogenate was centrifuged at 4,000rpm $(3,500 \mathrm{xg})$ for 15 minute at $5^{\circ} \mathrm{C}$ in a cooling centrifuge to get a clear saline supernatant. The procedure is repeated to get ethanol supernatant. Aqueous extract in ice- cold saline was used for estimation of biochemical constituents like carbohydrate and protein and ethanol extract was used for lipid estimate.

\section{Estimation of Moisture}

The following equation was used to determine the moisture content of the dry fish sample: Percentage $(\%)$ of moisture $=($ weight of the sample - weight of the Dried sample)/weight of the sample

\section{Estimation of carbohydrate}

Carbohydrate content of the fish tissues was estimated by Anthrone reagent as described. ${ }^{11}$ The carbohydrate content was expressed in percentage $(\%)$.

\section{Estimation of protein}

Total protein was determined by method. ${ }^{12}$ The protein content was expressed in percentage (\%).

\section{Estimation of lipid}

Total lipid was estimated by the following the method. ${ }^{13}$ The lipid content was expressed in percentage (\%).

\section{Estimation of Ash Content}

The following equation was used to determine the ash content of the dry fish samples. Ash $(\%)=($ weight of ash $/$ weight of the sample $) \times 100$

\section{Data collection}

The data for Biochemical parameters were analyzed using one-way analysis of variance and the difference in the means between groups were tested for significance at the $95 \%$ confidence level. P values < 0.05 were considered to be significant; using Duncan's multiple range tests. All statistical analyses were performed using the SPSS software Package, Version 11.5.

\section{Results and discussion}

\section{Nutritional Evaluation}

Fishery products are important not only from a nutritional point of view, but also as an item of international trade and foreign exchange corner for a number of countries in the world. Fish and shellfish are highly perishable, and prone to vast variations in quality due to differences in species, environmental habitats and feeding habits. The freshness of fish is affected by poor handling, transportation, and decorboxylation. In the present study biochemical parameters like moisture, protein, carbohydrate and Ash content from three types of edible marine fishes viz., Elops saurus, Lutjanus ebae and Carangoides malabaricus were estimated and represented in (Figure 1-6). Moisture is one of the major components of all species and all types of fish. The percentage of moisture is good indicator of its relative contents of energy, proteins and lipid. The result specifies that the moisture content of fresh marine fishes were more than the market fishes, which ranged from $60.0 \%$ to $76.5 \%$ The Carbohydrate content of fresh marine fishes, were ranged from $5.1 \%$ to $7.6 \%$, which is higher than the market fishes. Fishes are known to be a source of protein rich in essential amino acids (lysine, methionine, cystine, threonine and tryptophan). ${ }^{14}$ From the analysis of protein content, fresh marine fishes ranged from $15.5 \%$ to $21.5 \%$ and it was higher than the market fishes. Protein and lipid are the major nutrients in fish and their levels help to define the nutritional status of the particular organism. ${ }^{15}$ Fish and shellfish are highly perishable, and prone to vast variations in quality due to differences in species, environmental habitats, feeding habits and action of autolysis enzymes as well as hydrolytic enzymes of microorganisms on the fish muscle. ${ }^{16}$ The lipid content of fishing site fishes ranged from $1.3 \%$ to $3.2 \%$ and it was higher than the market fishes. Generally fish can be grouped into four categories according to their fat content lean fish, low fat ( 2 to $4 \%$ ), medium fat (4 to $8 \%$ ), and high fat. ${ }^{17}$ The marine fishes (Lutjanusquin quelineatus and Scolopsis bimaculatus) had higher lipid content than other fishes; hence they were classified as high fat group. The observed range of ash content in the fishes indicated that the species is a good source of minerals such as calcium, potassium, and iron. Ash is a measure of the mineral content of food item. It is the inorganic residue that remains after the organic matter has been burnt off. A good source of instant energy that comes to the mind is carbohydrate. It also helps in the body's development and growth. ${ }^{18}$ The Ash content of fresh marine fishes were ranged from $4.56 \%$ to $2.01 \%$, this was higher than the market fish.Small indigenous finfish species had considerable range of ash content but the percentage of occurrence was low compared with crustaceans. ${ }^{19}$ However, the findings of this study show that's the comparison between the average nutritional level of landing site fishes and market fishes. Fish quality is a complex concept involving a whole range of factors, which for the consumer include for example: safety, nutritional quality, availability, convenience and integrity, freshness, eating quality and the obvious physical attributes of the species, size and product type. Information about handling, processing and storage techniques, including time and temperature histories that can affect the freshness and quality of the products is very important for the partners in the chain. ${ }^{18}$ The quality of fish landings in the country is generally poor and wastage is high, especially in catches of multi-day boats. About $25-30 \%$ of the fish catched and landed by these boats is of poor quality, as the fish holds of these boats are not refrigerated. These type of catching aim at quantity rather than quality, and sell the poorer quality or spoiled fish to dried fish processors at a low price. Lack of knowledge regarding improved fish handling and post-harvest practices has contributed to the poor quality of fish and fishery products. ${ }^{19}$

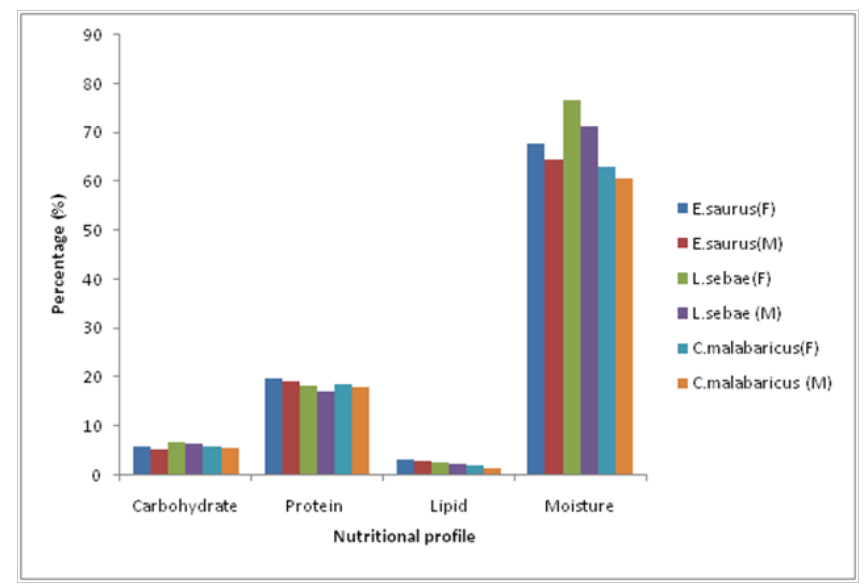

Figure I Average analyzed nutrient profile of Elope saurus, Lutjanus sebae and Carangoides malabaricus (15.12.14). 


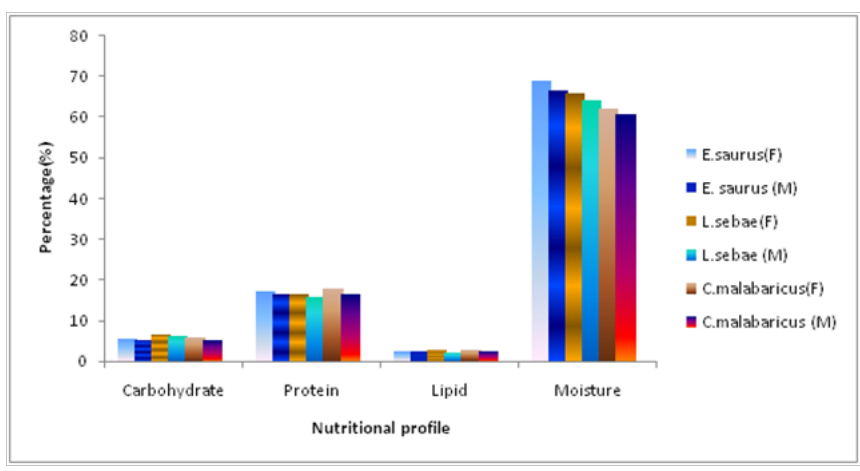

Figure 2 Average analyzed nutrient profile of Elope saurus, Lutjanus sebae and Carangoides malabaricus (30.12.14).

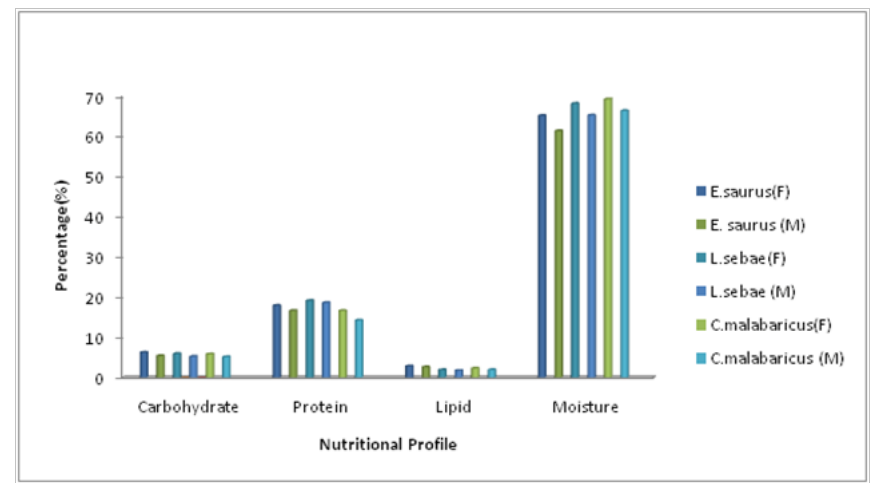

Figure 3 Average analyzed nutrient profile of Elope saurus, Lutjanus sebae and Carangoides malabaricus (14.0I.15).

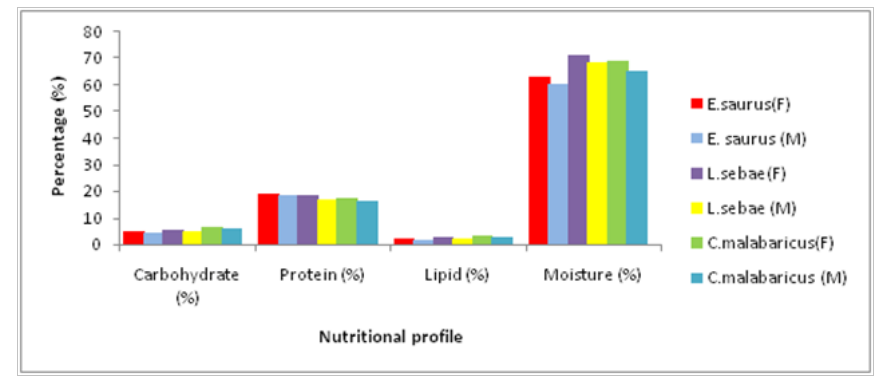

Figure 4 Average analyzed nutrient profile of Elope saurus, Lutjanus sebae and Carangoides malabaricus (29.0I.15).

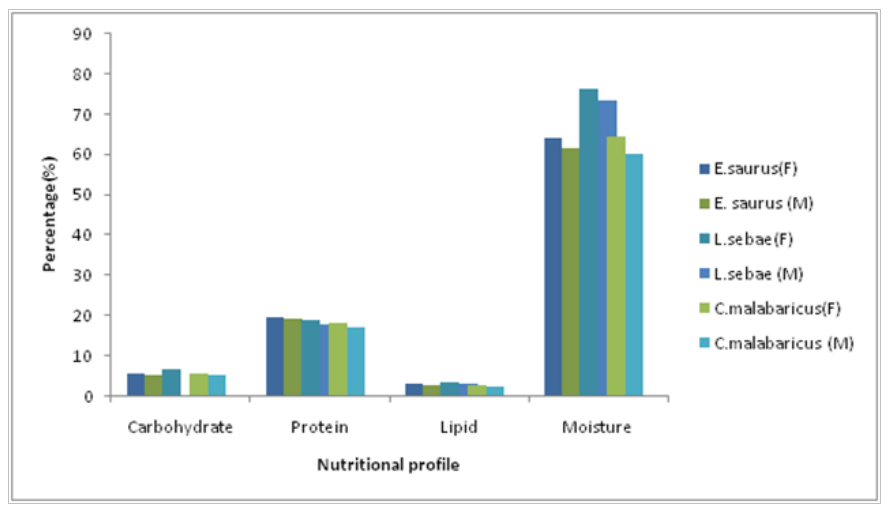

Figure 5 Average analyzed nutrient profile of Elope saurus, Lutjanus sebae and Carangoides malabaricus (13.02.15).

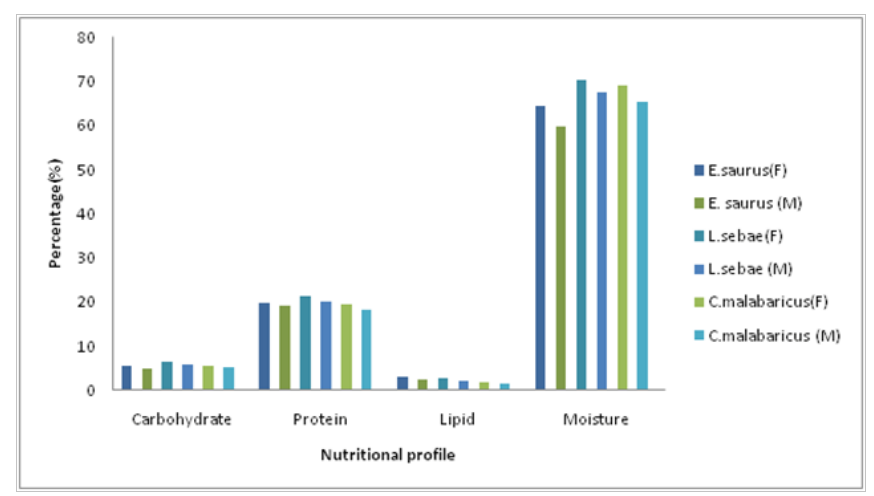

Figure 6 Average analyzed nutrient profile of Elope saurus, Lutjanus sebae and Carangoides malabaricus (28.02.15).

\section{Conclusion}

The present study reveals that the proximate compositions of three types of marine raw fishes from fishing site have very good nutritional value than the market fishes. The fishing site samples were very rich in protein, lipid and carbohydrate. However, the reduction of nutritional value of market fishes are greatly deteriorates due to longer storage and the formation of adenosine tri phosphate by series of reactions. Certainly one reason for the rather poor reputation of fish in the past has been poor quality due to lack of rapid transport; nowadays, with modern techniques for freezing, storing and transporting fresh fish, the consumer can receive fish that has a composition and flavour virtually unchanged from when it was caught, and should do so to an ever increasing extent in the future. Therefore, the fish sellers should be kept more precautionary steps during storage of fish from the fishing site to market and in the sales centre.

\section{Acknowledgments}

We wish to thank the authorities of Yadava College, Madurai for providing the necessary facilities. We also thank the anonymous referees for their valuable comments, which greatly improved our manuscript.

\section{Conflicts of interest}

None.

\section{References}

1. Spencer H, Samachson, Fowler J, et al. Availability in man of protein and minerals from fish protein concentrate. Am J Clin Nutr. 1971;24(3):311317

2. Jaclyn M, Stacey JB, Ashley SR. Omega-3 fatty acids and pregnancy. Rev Obstet Gynecol. 2010;3(4):163-171.

3. Jinadasa BKKK. Determination of Quality of Marine Fishes Based on Total Volatile Base Nitrogen test (TVB-N). Nat Sci. 2014;12(5):106111.

4. Venugopal V. Biosensors in fish production and quality control. Biosens Bioelectronics. 2002;17(3):147-157.

5. Eritsland J, Arnesen H, Seljeflot I, et al. Long-term metabolic effects of $\mathrm{n}-3$ polyunsaturated fatty acids in patients with coronary artery disease. Am J Clin Nut. 1995;61(4):831-836.

6. Davis DA, Samocha TM, Bullis RA, et al. Practical diets for Litopenaeus vannamei (Boone, 1931): working towards organics and/or all plant production diets. Hermosillo, Mexico. 2004;pp.202-214. 
7. New MB, Wijkstom UN. Use of Fishmeal and Fish Oil in Aquafeeds: Further Thoughts on the Fishmeal Trap. FAO United Nations, Rome. 2002.

8. Zygmunt USR, Joanna A. Protein quality and amino acid profiles of fish products available in Poland. Food Chemistry. 2009;112:139-145.

9. Abbas KA, Mohamed M, Jamilah B, et al. A review on correlations between fish freshness and $\mathrm{pH}$ during cold storage. American journal of biochemistry and biotechnology. 2008;4:416-421.

10. Sankar SP, Sujith S, Jayalakshmi V. Microbial study and Proximate Composition of Six Marine fish species in Mudasalodai Coastal Region IJPBS. 2013;3(3):398-404.

11. Seifter S, Daton S, Novic B, et al. The estimation of glycogen with the anthrone reagent. Arch. Biochem. Biophys. 1950;25(1):191-200.

12. Lowry OH, Rosebrough NJ, Farr AJ, et al. Protein measurement with the Folin phenol reagent. $J$ biol Chem. 1951;193(1):265-275.

13. Folch J, Lees M, Sloane Stanley GH. A simple method for the isolation and purification of total lipids from animal tlssues. $J$ Biol Chem. 1957;226(1):497-509.
14. Muraleedharan VKP, Antony PA, Perigreen K. Utilization of unconventional fish resources for surimi preparation. Proceedings of the second workshop on scientific results of FORV SAGAR Sampada, Dept of ocean development, India. 1996;pp:539-543.

15. Osibona AO, Kusemiju K, Akande GR. Proximate composition and fatty acids profile of the African catfish Clarias gariepinus. Journal of Food Agriculture, Nutrition and Development. 2006;3(1):1-5.

16. Ackman RG. Nutritional composition of fats in sea foods. Prog. Food Nutrition Sci. 1989;13(3-4):161-289.

17. Payne SA, Johnson BA, Otto RS. Proximate composition of some northeastern Pacific forage fish species. Fish Oceanography. 1999;8(3):159 177.

18. Mazumder MSA, Rahman MM, Ahmed ATA, et al. Proximate Composition of Some Small Indigenous Fish Species (SIS) in Bangladesh. Int. J. Sustain Crop Prod. 2008;3(3):18-23.

19. FAO. Fishery and aquaculture country profiles, Sri Lanka. Food and Agriculture Organization of the United Nations, Rome, Italy. 2013. 